should be considered in international policies concerned with arms availability and transfer.

Contributors: DRM conducted the analysis and interpretation of the data, discussed core ideas, and wrote the paper. SMO initiated and coordinated the collection of data, discussed core ideas and interpretation of the data, and participated in writing the paper. DRM is guarantor of the paper

Funding: No additional funding.

Competing interests: None declared.

1 Boutwell J, Klare MT, Reed LW, eds. Lethal commerce: the global trade in small arms and light weapons. Cambridge, MA: Committee on International Security Studies, American Academy of Arts and Sciences, 1995.

2 Williams P. Transnational organised crime and international security: a global assessment. In: Gamba V, ed. Society under siege: crime, violence and illegal weapons. Halfway House, South Africa: Institute for Security Studies, 1997:11-41.

3 Meddings DR. Weapons injuries during and after periods of conflict: retrospective analysis. BMJ 1997;315:1417-20.

4 Zawels EA, Stedman SJ, Daniel DCF, Cox D, Boulden J, Tanner F, et al. Managing arms in peace processes: the issues. Geneva: United Nations Institute for Disarmament Research, 1996.
5 Wang J. Aborted disarmament. In: Managing arms in peace processes: Cambodia. Geneva: United Nations Institute for Disarmament Research 1996:32-82. (Disarmament and conflict resolution project.)

6 Coupland RM. Epidemiological approach to surgical management of the casualties of war. BMJ 1994:308:1693-7.

7 Asia Watch, Physicians for Human Rights. Land mines in Cambodia: the cowards'war. Boston: Asia Watch, Physicians For Human Rights, 1991.

8 Andersson N, da Sousa C, Paredes S. Social cost of land mines in four countries: Afghanistan, Bosnia, Cambodia, and Mozambique. BMJ 1995;311:718-21.

9 Cobey JC, Flanagin A, Foege WH. Effective humanitarian aid. Our only hope for intervention in civil war. JAMA 1993;270:632-4.

10 Comninellis N. War and health: a view of Africa. Tropical Doctor $1994 ; 24(1): 1-3$

11 Aboutanos MB, Baker SP. Wartime civilian injuries: epidemiology and intervention strategies. J Trauma 1997;43:719-26.

12 Weinberg J, Simmonds S. Public health, epidemiology and war. Soc Sci Med 1995;40:1663-9.

13 Grossman D. On killing: the psychological cost of learning to kill in war and society. Boston: Little, Brown, 1995.

14 Coupland RM, Samnegaard HO. Effect of type and transfer of conventional weapons on civilian injuries: retrospective analysis of prospective data from Red Cross hospitals. BMJ 1999;319:410-2.

(Accepted 30 June 1999)

\title{
Incidence of weapon injuries not related to interfactional combat in Afghanistan in 1996: prospective cohort study
}

\author{
Markus Michael, David R Meddings, Salah Ramez, Juan Luis Gutiérrez-Fisac
}

\begin{abstract}
Objective To examine the descriptive epidemiology of weapon injuries not directly attributable to combat during armed conflict.

Design Prospective cohort study.

Setting Nangarhar region of Afghanistan, which experienced effective peace, intense fighting, and then peace over six months in 1996.
\end{abstract}

Subjects 608 people admitted to Jalalabad hospital because of weapon injuries.

Main outcome measures Estimated incidence of injuries from combat or otherwise (non-combat injury) before, during, and after the fall of Kabul. Results Incidence of non-combat injury was initially 65 per 100 000. During the intense military campaign for Kabul the incidence declined dramatically, and then differentially increased dependent on injury subcategory - that is, whether injuries were accidental or intentional and whether they were inflicted by firearms or fragmenting munitions. Non-combat injuries accounted for $51 \%$ of weapon injuries observed over the study period. Civilians were more likely to have non-combat injuries than combat injuries.

Conclusions Weapon injuries that are not attributable to combat are common. Social changes accompanying conflict and widespread availability of weapons may be predictive of use of weapons that persists independently of conflict.

\section{Introduction}

Television images of children clutching kalashnikov rifles underscore the fact that in many regions weapons designed for use by trained armed forces are no longer in military hands. ${ }^{12}$ This has been argued to contribute to social violence more generally. ${ }^{34}$
In 1993 the International Committee of the Red Cross began supporting the surgical activities of Jalalabad hospital, 120 kilometres east of Kabul in the Nangarhar region of Afghanistan. Under control of a single authority, this region had not experienced interfactional combat since 1992. On 10 September 1996 the Taliban faction overran Jalalabad without bloodshed and launched its final offensive on Kabul, which fell on 26 September. We examined weapon injuries over six months, before, during, and after the battle for Kabul.

\section{Patients and methods}

From 1 June 1996 to 30 November 1996 all people admitted to Jalalabad hospital with weapon injuries were given a structured interview eliciting demographic information and circumstances surrounding injury. Since Jalalabad hospital was the sole surgical facility in the region, we believe our study includes almost all people injured by weapons in Nangarhar who survived to reach hospital.

The category civilian included all women and girls, boys (aged under 16), and men aged 50 and older. Mine injuries were not included because of the passive way in which they inflict injury. Injuries were classed as combat injuries if they had been sustained during interfactional combat. All other injuries were classed as non-combat injuries and further categorised into accidents, violence, or tribal fighting. Classification of injury was assigned by one of us (MM) on the rare occasions that it was ambiguous.

We calculated the incidence of weapon injury for the whole study and before, during, and after the battle for Kabul. These rates were calculated for an estimated regional population at the mid-point of the study period on the basis of data provided by the United Nations High Commissioner for Refugees.
Editorial by Smith Health Operations Division, International Committee of the Red Cross, 19 avenue de la Paix, 1202 Geneva, Switzerland

Markus Michael health and relief coordinator, Asia and Latin America desk

Unit of the Chief

Medical Officer,

International

Committee of the

Red Cross

David R Meddings

epidemiologist

International

Committee of the Red Cross,

Peshawar, Pakistan

Salah Ramez

surgeon

Department of

Preventive Medicine and Public Health,

Autonomous

University of

Madrid, Arzobispo

Morcillo s/n, 28029

Madrid, Spain

Juan Luis

Gutiérrez-Fisac

associate professor

Correspondence to: Dr Meddings

dmeddings@icrc.org

BMJ 1999;319:415-7 
Table 1 Descriptive data for patients with weapon injuries. Values are numbers (percentages) of patients unless stated otherwise

\begin{tabular}{lccc} 
& All injuries & Combat injuries & $\begin{array}{c}\text { Non-combat } \\
\text { injuries }\end{array}$ \\
\hline Adults $(\geqslant 16)$ & $516(85)$ & $256(86)$ & $260(84)$ \\
\hline Children (0-15) & $92(15)$ & $41(14)$ & $51(16)$ \\
\hline Civilians* ${ }^{*}$ & $198(33)$ & $75(25)$ & $123(40)$ \\
\hline Male & $547(90)$ & $243(95)$ & $221(85)$ \\
\hline Median age (years) & 25 & 26 & 25 \\
\hline Admissions: & 608 & 297 & 311 \\
\hline All weapons & $280(46)$ & $77(26)$ & $203(65)$ \\
\hline Firearms & $309(51)$ & $216(73)$ & $93(30)$ \\
\hline Fragmenting munitions $\dagger$ & $19(3)$ & $4(1)$ & $15(5)$ \\
\hline Other $\neq$ & & & 1.9 \\
\hline In-hospital mortality (\%): & 2 & 2 & 3 \\
\hline All weapons & 2.9 & 2.6 & 0 \\
\hline Firearms & 1.3 & 1.9 & 0 \\
\hline Fragmenting munitions $\dagger$ & 0 & 0 & \\
\hline Other $\neq$ & & &
\end{tabular}

${ }^{*}$ Women and girls, boys (under 16), and men $\geqslant 50$.

†Includes bombs, shells, and grenades.

†Primarily knives or blunt weapons.

Table 2 Numbers of admissions and annual incidences of combat and non-combat injuries by time period

\begin{tabular}{|c|c|c|c|c|}
\hline \multirow[b]{2}{*}{ Time period } & \multicolumn{2}{|c|}{ No of admissions } & \multicolumn{2}{|c|}{ Annual incidence per 100000 population } \\
\hline & $\begin{array}{l}\text { Combat } \\
\text { injuries }\end{array}$ & $\begin{array}{c}\text { Non-combat } \\
\text { injuries }\end{array}$ & $\begin{array}{l}\text { Combat } \\
\text { injuries }\end{array}$ & $\begin{array}{l}\text { Non-combat } \\
\text { injuries }\end{array}$ \\
\hline Study (1 Jun-30 Nov 1996) & 297 & 311 & 39 & 41 \\
\hline \multicolumn{5}{|l|}{ Fall of Kabul: } \\
\hline Before (1 Jun-9 Sep 1996) & 0 & 269 & 0 & 65 \\
\hline During (10 Sep-26 Sep 1996) & 235 & 3 & 335 & 4 \\
\hline After (27 Sep-30 Nov 1996) & 62 & 39 & 23 & 15 \\
\hline
\end{tabular}

\section{Results}

Table 1 shows the characteristics of the 608 patients comprising our study population. Another 149 people with mine injuries were not included in the analysis. Civilians were more likely to sustain non-combat than combat injuries (table $1, \mathrm{P}<0.001$ ). Non-combat injuries were inflicted principally with firearms, whereas combat injuries were inflicted principally with fragmenting munitions (bombs, shells, or grenades). In-hospital mortality was comparable to previous experience. ${ }^{36}$

Table 2 shows the numbers of admissions and the incidence of combat and non-combat injuries during the study and before, during, and after the battle for Kabul. The incidence of non-combat injury was high over the six months (41 per 100000 ) but declined sharply during the battle for Kabul, rising subsequently (table 2).

Table 3 gives a breakdown of the incidence of noncombat injury by type and time period. Apart from a car bomb explosion in June and a tribal clash in August, almost all non-combat injuries were caused by firearms. The increased incidence of non-combat injury after the fall of Kabul was principally due to accidental injuries from firearms.

\section{Discussion}

We found a high incidence of weapon injury in a heavily militarised setting without interfactional combat.

\section{Limitations of study}

Four limitations of this study deserve comment.

Firstly, we underascertained injuries because we included only those who reached hospital. For every American killed in the field in Vietnam between 1.5 and 3 people were wounded and reached care ${ }^{7}$; in Vietnam, evacuation time was probably about 1 hour for American casualties. Underascertainment was probably substantial in our study because access times were considerably longer.

Secondly, we inferred that the availability of weapons was high without measuring it. However, the extent of arms transfers into Afghanistan has been reported to be immense. ${ }^{8}$

Thirdly, injuries may have been misclassified, although this probably occurred only rarely. Classification criteria were unambiguous, and few cases required designation of category.

Finally, our population estimate may be inaccurate, but it was calculated from the best available data and is comparable to the estimate provided by regional authorities.

\section{Non-combat injuries from firearms}

Before the Taliban takeover of Jalalabad the incidence of non-combat injuries from firearms was 38 per 100000 population per year. This is about the annual incidence of firearm injuries in the United States, reported to be 39 per $100000 .^{9}$

The United States is unique in terms of violence caused by firearms, with rates of intentional death from firearms that far exceed those in other countries. ${ }^{10}$ Our observed incidence is probably lower than the true incidence. In addition, handguns cause many of the injuries from firearms in the United States, but AK-47 assault rifles caused most of the firearm injuries in our study. The increased kinetic energy of individual projectiles and higher rates of fire achieved by AK- $47 \mathrm{~s}$ imply that people in our study would be likely to have more severe injuries.

Impulse and ready access to firearms are thought to play an important part in firearm injuries, ${ }^{11}{ }^{12}$ a combination which would probably have been potentiated

Table 3 Incidences of non-combat injury per 100000 population by time period and type of weapon

\begin{tabular}{|c|c|c|c|c|c|c|c|}
\hline \multirow[b]{2}{*}{ Time period } & \multicolumn{2}{|c|}{ Firearms } & \multicolumn{2}{|c|}{ Fragmenting munitions* } & \multicolumn{2}{|c|}{ Tribal fighting } & \multirow[b]{2}{*}{ Other } \\
\hline & Accidental & Intentional & Accidental & Intentional & Firearms & $\begin{array}{l}\text { Fragmenting } \\
\text { munitions* }\end{array}$ & \\
\hline Study (1 Jun-30 Nov 1996) & 18 & 8 & 1 & 4 & 1 & 8 & 2 \\
\hline \multicolumn{8}{|l|}{ Fall of Kabul: } \\
\hline Before (1 Jun-9 Sep 1996) & 24 & 14 & 1 & 7 & 2 & 14 & 3 \\
\hline During (10 Sep-26 Sep 1996) & 3 & 0 & 0 & 0 & 0 & 0 & 1 \\
\hline After (27 Sep-30 Nov 1996) & 12 & 2 & 0 & 0 & 0 & 0 & 1 \\
\hline
\end{tabular}

*Includes bombs, shells, and grenades. 
by the lack of a functioning judiciary in Jalalabad. Most intentional injuries arose during family disputes, followed by disputes over land and people breaking up altercations. Most accidental injuries were self inflicted, followed by stray bullets and of unknown origin. Women and children primarily sustained accidental injuries while an assault rifle was being cleaned in the home.

A remark should also be made about the tribal clash that occurred during our study. While probably always a feature of Afghan rural life, tribal fighting tended to be small scale, with individual assaults avenged on a case by case basis. We believe that the influx of weaponry from the larger intrastate conflict has profoundly changed the way in which these disputes are played out. In the tribal fighting during our study, $90 \%$ of those reaching hospital were injured by fragmenting munitions, and over a quarter of these were women or children.

\section{Conclusions}

The enduring consequences of widespread availability of weapons have been less emphasised than those of landmines. Nevertheless, recent initiatives such as programmes to buy back weapons and reintegrate combatants into peacetime occupations have addressed the issue. ${ }^{13}{ }^{14}$ Such programmes face serious challenges. Programmes that buy back weapons can fuel demand for weapons, and providing a social and economic environment where people feel secure to relinquish weapons is easily obstructed by those with opposing vested interests. ${ }^{15} 16$

From a public health perspective, this suggests efforts should include, if not favour, primary prevention. Widespread availability of military weapons and accompanying social changes are likely to facilitate social violence that arises as a side effect of and subsides independently from conflict. Doctors and others concerned with the health of populations should bring this to the attention of policy makers and others who are concerned by the arms trade and its implications.

Contributors: MM initiated and coordinated the collection of data, discussed core ideas and interpretation of the data, and participated in writing the paper. DRM conducted the analysis and interpretation of the data, discussed core ideas, and wrote the paper. SR participated in the study design, data collection and analysis, and discussed core ideas. JLG-F participated in the design, analysis, and interpretation of the data and contributed to the paper. DRM is guarantor of the paper.

Funding: No additional funding.

Competing interests: None declared.
Key messages

- A region in Afghanistan experienced peace, intense combat, and then peace in 1996

- During peace the incidence of injury from weapons was high, the incidence of injury from firearms being similar to that in the United States

- Over half of all weapon injuries were not attributable to interfactional combat

- Weapon availability and social breakdown accompanying conflict may be important factors in the occurrence of weapon injuries that persist independently of conflict

1 Boutwell J, Klare MT, Reed LW, eds. Lethal commerce: the global trade in small arms and light weapons. Cambridge, MA: Committee on International Security Studies, American Academy of Arts and Sciences, 1995.

2 Williams P. Transnational organised crime and international security: a global assessment. In: Gamba V, ed. Society under siege: crime, violence and illegal weapons. Halfway House, South Africa: Institute for Security Studies, 1997:11-41.

3 Meddings DR. Weapons injuries during and after periods of conflict: retrospective analysis. $B M J$ 1997:315:1417-20.

4 Zawels EA, Stedman SJ, Daniel DCF, Cox D, Boulden J, Tanner F, et al. Managing arms in peace processes: the issues. Geneva: United Nations Institute for Disarmament Research, 1996.

5 Coupland RM. Epidemiological approach to surgical management of the casualties of war. BMJ 1994;308:1693-7.

6 Coupland RM. The effects of weapons: defining superfluous injury and unnecessary suffering. Medicine and Global Survival 1996;3:1-6.

7 Bellamy RF. Anesthesia and perioperative care of the combat casualty. In: Combat trauma overview. Falls Church, VA: Office of the Surgeon General, United States Army, 1995:1-42.

8 Smith C. Light weapons and ethnic conflict in South Asia. In: Boutwell J, Klare MT, Reed LW, eds. Lethal commerce: the global trade in small arms and light weapons. Cambridge, MA: Committee on International Security Studies, American Academy of Arts and Sciences, 1995:61-76.

9 Annest JL, Mercy JL, Gibson DR, Ryan GW. National estimates of nonfatal firearm-related injuries. Beyond the tip of the iceberg. JAMA $1995 ; 273: 1749-54$

10 Cukier W. Firearms regulation: Canada in the international context Chronic Diseases in Canada 1998;19:25-34

11 Kellermann AL, Lee RK, Mercy JA, Banton J. The epidemiologic basis fo the prevention of firearm injuries. Annu Rev Public Health 1991;12:17-40.

12 Sloan JH, Rivara FP, Reay DT, Ferris JA, Kellermann AL. Firearm regulations and rates of suicide. A comparison of two metropolitan areas. $N$ Engl J Med 1990;322:369-73.

13 Higdon S, ed. Angola: conflict resolution and peacebuilding. London: Saferworld, 1996

14 Adeniji O. Regional arrangements to constrain the flow of arms into Central Africa. In: Lodgaard S, Ronnfeldt C, eds. A moratorium on light weapons in West Africa. Oslo: Norwegian Institute of International Affairs, 1998:85-92.

15 Berman E. Demobilization and disarmament. In: Managing arms in peace processes: Mozambique. Geneva: United Nations Institute for Disarmament Research, 1996:57-80.

16 Chachiua M. Arms management programme: Operations Rachel 1996-1999. Pretoria: Institute for Security Studies, 1999

(Accepted 30 June 1999)

\section{Email submissions from outside the United Kingdom}

We are now offering an email submission service for authors from outside the UK. The address is papers@bmj.com

Ideally our email server would link seamlessly with our manuscript tracking system, but for now it does not, which is why we are offering the service only to authors outside the UK. Most post in the UK arrives the next day, so UK authors have the least to gain in speed of delivery from email delivery. As soon as our systems improve we will invite email submissions from everyone.

If you choose to send your submission by email please would you send the text and any tables and figures as attached files, together with a covering letter giving all your contact details (postal address, phone, fax, and email address). We can read files created with most word processing, graphics, and spreadsheet programs.

When your submission is received in our email box you will receive an automatic acknowledgment to show that it has arrived. If the submission is incomplete we will contact you and ask you to resend the missing information.

Once the submission is complete we will register it on our manuscript tracking system and you will receive a standard acknowledgment in the post.

Letters to the editor should continue to be sent direct to www.bmj.com as rapid responses or toletters@bmj.com 